\title{
EFFECTS OF HIGH-SPEED RAIL
}

CONSTRUCTION ON THE EVOLUTION OF

INDUSTRIAL AGGLOMERATION: EVIDENCE FROM THREE GREAT BAY AREAS IN CHINA

\section{Lei Fang ${ }^{1}$, Xuewei Zhang ${ }^{2}$, Zihua Feng ${ }^{3}$, Ce Cao ${ }^{4}$}

\footnotetext{
1 Henan University of Economics and Law, School of Finance, China, ORCID: 0000-0002-3029-1828, fangeconomy@126.com;

2 Beijing University of Technology, School of Economics and Management, China, ORCID: 0000-0002-6085-3377, zhangxuewei219@126.com;

3 Henan University of Science and Technology, School of Economics, China, ORCID: 0000-0002-7946-6756, fengzhstudy@163.com;

4 University of Exeter, School of Business, United Kingdom, ORCID: 0000-0001-5561-1237, caoce1636@163.com.
}

\begin{abstract}
High-speed rail is an important transportation infrastructure that can promote regional economic growth and adjust industrial layout. To explore the impact of high-speed rail construction on the industrial spatial layout of China's Bay Area, the effects of high-speed rail construction on industrial spatial layout of the Circum-Bohai Great Bay Area, the Circum-Yangtze Estuary Great Bay Area, and the Guangdong-Hong Kong-Macao Greater Bay Area in China were analyzed by using DID (difference-in-differences) model and quantile treatment effect based on the panel data obtained from 2005 to 2016. Results demonstrate that high-speed rail construction significantly affects industrial spatial layout of urban areas. Due to high-speed rail construction, manufacturing and real estate industries in the Circum-Bohai Great Bay Area expand greatly and show a significant diffusion effect. This diffusion promotes agglomeration of wholesale and retail, real estate, transportation, warehousing, and post industries in small cities. High-speed rail construction exhibits an agglomeration effect on financial industry in the Circum-Yangtze Estuary Great Bay Area. Highspeed rail construction facilitates clustering of manufacturing, financial, and transportation industries in small cities. The impact of high-speed rail construction on manufacturing, accommodation and catering, financial, transportation, warehousing, and post industries in Guangdong-Hong KongMacao Greater Bay Area shows a diffusion effect. In sum, high-speed rail construction causes an evolution of industrial agglomeration in three great bay areas in China. The conclusion provides decision references for optimization of industrial spatial layout in great bay areas.
\end{abstract}

Keywords: High-speed rail, industrial agglomeration, three Great Bay Area, DID model, quantile treatment effect.

JEL Classification: L92, P25, R41.

APA Style Citation: Fang, L., Zhang, X., Feng, Z., \& Cao, C. (2020). Effects of High-speed Rail Construction on the Evolution of Industrial Agglomeration: Evidence from Three Great Bay Areas in China. E\&M Economics and Management, 23(2), 17-32. https://doi.org/10.15240/ tul/001/2020-2-002

\section{Introduction}

The economy of China has been maintaining a middle and high growth rates in the past 40 years since reform and opening-up. Railway is an important infrastructure and a major factor of economic development. It is also a witness and beneficiary of reform and opening-up. Railway in China has undergone transformation and development. Given the continuous expansion of traffic network and 
innovative reform of technologies, high-speed rail construction has achieved outstanding progresses. During the "12th Five-Year Plan," the total investment of China to high-speed rail system has exceeded 1,800 billion RMB. Moreover, 3,500 billion RMB of investment is expected under railway plan in the "13th FiveYear Plan." Currently, China owns a high-speed rail network with the longest operation miles, the highest transportation density, and the most complicated network operation scenario in the world (Karolys et al., 2019). By the end of 2018, the operation miles of China's high-speed rail network have accounted for approximately $66 \%$ of global high-speed rail (Delaplace \& Dobruszkes, 2015; Dobruszkes et al., 2017). In the general background of deepening reform, bay area economy is a new open mode and economic form within bay areas. Thus, great bay area becomes an important growth pole that drives economic development through its technological innovation and industrial radiation (Xie, 2018). High-speed rail construction determines the economic development level and speed and influences industrial agglomeration level in great bay areas. Therefore, studying high-speed rail construction has a practical significance to industrial development in bay areas.

High-speed rail construction cannot only shorten traveling time across different cities but also lower the trade cost of industrial chains and improve transregional talent and technological flows. Thus, high-speed rail construction may influence industrial spatial layout to some extent (Givoni \& Chen, 2017; Wang et al., 2017). High-speed rail systems in the Circum-Bohai Great Bay Area, the Circum-Yangtze Estuary Great Bay Area, and the Guangdong-Hong Kong-Macao Greater Bay Area are constructed from point to axis and from axis to surface. The stereoscopic transportation network structure strengthens the spatial economic ties of three great bay areas, accelerates the flow among different production elements, and expands the radiation range. Thus, it significantly affects industrial layout. Large-scaled construction of high-speed railway network will accelerate and magnify integration effect of urban agglomerations and promote resource redistribution among different cities and industrial integration and disintegration (Henderson \& Wang, 2007). Industrial agglomeration effect in great bay areas in the era of high-speed rail refers to changes of regional advantages and industrial spatial layout, thus lowering the trade cost and forming scale effects. Bay area economy is a significant mark in world-class cities. According to a report of the State Council of China in 2017, promoting deep cooperation among China mainland, Hong Kong, and Macao and exploring development plans for the Guangdong-Hong Kong-Macao Greater Bay Area are significant to improve its position and role in national economic development and open-up policy. Thus, the construction of Guangdong-Hong Kong-Macao Greater Bay Area has been promoted to a national strategy. At present, the Circum-Yangtze Estuary Great Bay Area and the Circum-Bohai Great Bay Area remain under the planning stage. After the construction of the three bay areas, China will have south, east, and north great bay areas, namely, the Guangdong-Hong Kong-Macao Greater Bay Area, the Circum-Yangtze Estuary Great Bay Area, and the Circum-Bohai Great Bay Area, respectively. These three great bay areas are developed and radiated outward by making Pearl River Estuary ring, Yangtze River ring, and Bohai Bay as their centers. The "high-speed rail + great bay area" system broke the original industrial spatial equilibrium in great bay areas. Given the connections of high-speed rail, the positional advantages are improved and industrial agglomeration effect or diffusion effect is observed.

In sum, high-speed rail denotes an economic tie within a region and across different regions. It has also exhibited significant externality and networking. High-speed rail affects economic development to some extent. It is an important prerequisite and promotion mechanism of industry agglomeration. However, only few studies have discussed influences of high-speed rail construction on industrial spatial layout in bay areas. Therefore, this study aims to investigate the effects of high-speed rail construction on the evolution of industrial agglomeration in three great bay areas to propose reasonable suggestions to industrial spatial layout.

The remaining parts of this study are organized as follows. Section 1 reviews existing studies on the influences of high-speed rail construction on economic development. Section 2 introduces the difference-in-differences (DID) model, quantile treatment effect, and variable specifications. Section 3 performs 
an empirical study on the effects of high-speed rail construction on industrial agglomeration in three bay areas in China. Moreover, a descriptive statistical analysis is carried out. Section 4 discusses the different effects of high-speed rail construction on industrial spatial layout in three great bay areas in China. Final section presents the conclusion. This study provides a new idea for the selection of development path in bay areas in China.

\section{Literature Review}

Recently, theoretical discussions and empirical tests on the effects of high-speed rail have been carried out. High-speed rail construction can improve accessibility and market development potentials of different regions. These benefits are significant to strengthen economic ties and fast flow of production factors across different cities, thus influencing industrial development in urban areas. Scholars are limited within a quantitative analysis on the effects of a highspeed railway on industrial agglomeration in a region. Existing studies concluded that highspeed rail can significantly increase the flow of production factors, expand their scale effect, realize the optimal configuration of resources, increase employment density in urban service industry (Shao et al., 2017), and promote development of service and tourism industries (Givoni, 2006). Given the advantages of high speed and high transportation capacity, high-speed rail can promote economic agglomeration in cities along tourism and real estate paths. Tertiary industry depends on the flow of information, knowledge, and talents. Thus, more enterprises belonging to the tertiary industry may concentrate in cities with highspeed railway stations to obtain convenient services. As a result, economic agglomeration effect is generated (Levinson, 2012; Shaw et al., 2014; Cosido-Cobos et al., 2018). In addition to its direct effects on the service industry, high-speed rail services release more railway resources, increase freight transport capacity, and facilitate transformation and development of the manufacturing industry. $\mathrm{Li}$ and Su (2017) investigated agglomeration effects of Beijing-Guangzhou high-speed railway on manufacturing industry based on panel data during 2000-2014. Results showed that agglomeration affects undergone three stages, namely, accelerating stage, weakening stage, and diffusion stage. Zhao and Chen
(2018) analyzed the effects of BeijingShanghai high-speed rail on manufacturing and business service industries. According to empirical results, high-speed rail significantly affected manufacturing and business service industries and slightly influenced non-business service industry.

High-speed rail may exert different effects on different regions and cities (Hall, 2009; Coto-Millán et al., 2007; Chen, 2012), given that it is mainly concentrated in Eastern and Central China. High-speed rail network promotes connections across cities with high social economic benefits and increases the agglomeration economies in cities along a specific region (Yang et al., 2018). Significant changes have taken place in spatial redistribution of economic activities due to frequency and fast flows of high-speed rail. With regard to investment activities, high-speed rail attracts capital inflows from second-tier cities and strengthens the position of core cities. With regard to consumption activities, high-speed rail attracts inflows from surrounding cities without high-speed rail (Li et al., 2016). The high-speed rail network brings commercial development of more lands, promotes further development of numerous industries (e.g. tourism, exhibition, real estate, information, and high-tech) (Verma et al., 2013; Yin et al., 2015), and accelerates regional economic development. However, high-speed rail may restrict economic development in some regions. Specifically, siphonic effect of big and central cities is further strengthened, which hinders the development of small cities (Cao et al., 2013; Vickerman, 2015; Urrutia-Azcona et al., 2018). Qin (2017) and Ke et al. (2017) found that high-speed rail promoted economic growth in cities with stations, but it also intensified the imbalance between Eastern and Western China. Thus, high-speed rail exerts direct or indirect effects while strengthening economic developments in bay areas. Compared with traditional transportation modes, high-speed rail optimizes the original transport network in a region and shortens the time distance across different regions (Monzón et al., 2013; Yin et al., 2015). High-speed rail also weakens barriers against transregional flow of production factors (e.g. labor force). Thus, adjusting industrial spatial layout in bay areas is recommended.

China is witnessing rapid economic growth caused by high-speed rail development. The 
industrial spatial layout in urban areas has been changed as a response to the formation of high-speed rail network. However, only few studies investigated the effects of high-speed rail on industrial agglomeration in bay areas. Therefore, this study aims to introduce highspeed rail into a model to discuss industrial spatial layouts in the Circum-Bohai Great Bay Area, the Circum-Yangtze Estuary Great Bay Area, and the Guangdong-Hong Kong-Macao Greater Bay Area.

\section{Methodology}

\subsection{Model}

DID model can be used to assess the implementation effect of a policy in economy and finance ability of a nation (Huhtala et al., 2018). High-speed rail construction can be viewed as a new policy experiment. In this study, samples are divided into cities with high-speed rail and cities without high-speed rail. In DID model, cities with high-speed rail in accordance with policy requirements are used as the experimental group, whereas cities without high-speed rail are used as the control group. The DID model is expressed as:

$$
\begin{aligned}
& L Q_{i t}=\beta_{0}+\beta_{1}^{*} H_{i t} T_{i t}+\beta_{2} A_{c c}+\beta_{i t} U r b_{i t}+ \\
& +\beta_{4} \operatorname{Hum}_{i t}+\beta_{5} F d i_{i t}+\beta_{6} \operatorname{Gov}_{i t}+\varepsilon_{i t}
\end{aligned}
$$

where $L Q_{i t}$ refers to agglomeration levels of eight industries (e.g. manufacturing industry; wholesale and retail industry; accommodation and catering industry; financial industry; real estate industry; renting and business service industry; transportation, warehousing, and post industry; and scientific research technological services and geological prospecting industry). $H_{i t} T_{i t}$ represents the selection variable of opening high-speed rail. $A c c_{i t}$ refers to accessibility level. $U r b_{i t}$ is the urbanization level. Hum $_{i t}$ is the wage level. $F d i_{i t}$ is the foreign investment level. Gov $v_{i t}$ is degree of government intervention. $\varepsilon_{i t}$ is the random disturbance term.

Quantile regression model can solve the estimation problem beyond the capability of traditional linear regression. In general, DID model is used to study the average effects of one policy on outcome variables (Tormo-Carbó et al., 2019). However, studies should consider the effects of a policy on conditional quantile of the outcome variable (i.e. quantile treatment effect) in addition to its effects on conditional expectation of the outcome variable. In this way, the relationship between dependent and independent variables at different levels can be analyzed. Moreover, quantile regression can effectively avoid heteroscedasticity problem in traditional regression analysis, given that it is based on the relationship between dependent and independent variables at different levels. Quantile regression of panel data model can be expressed as:

$$
\begin{aligned}
& Q_{y_{i t}}\left(\tau \mid X=x_{i t}\right)=x_{i t}{ }^{\prime} \beta_{\tau}+\alpha_{i} \\
& \beta_{\tau}=\arg \min \left[\tau \sum_{y \geq x^{\prime} \beta}\left|y-x^{\prime} \beta\right|+(1-\tau) \sum_{y \leq x^{\prime} \beta}\left|y-x^{\prime} \beta\right|\right]
\end{aligned}
$$

where $Q_{y_{t}}\left(\tau \mid X=x_{i i}\right)$ is the conditional $\tau$ quantile of the dependent variable $y$ when an explanatory variable $x_{i t}$ is given, $\beta_{\tau}$ is the $\tau$ quantile regression coefficient sequence of the corresponding dependent variable, $x_{i t}$ is an independent variable, and $\alpha_{i}$ is the intercept term of the model. $i$ refers to different sample individual, whereas $t$ is different time point for sample observation. Quantile regression of panel data can also be divided into fixed effect and random effect models. Given the

\section{Tab. 1: Comprehensive effects of high-speed rail on industrial agglomeration}

\begin{tabular}{l|c|c|c} 
& Before $(\boldsymbol{T}=\mathbf{0})$ & After $(\boldsymbol{T}=\mathbf{1})$ & Difference \\
\hline Cities with high-speed rail $(H=1)$ & $\beta_{0}+\beta_{1}$ & $\beta_{0}+\beta_{1}+\beta_{2}+\beta_{3}$ & $\Delta Y_{1}=\beta_{2}+\beta_{3}$ \\
\hline Cities without high-speed rail $(H=0)$ & $\beta_{0}$ & $\beta_{0}+\beta_{2}$ & $\Delta Y_{0}=\beta_{2}$ \\
\hline DID & & & $\Delta \Delta Y=\beta_{3}$ \\
\hline
\end{tabular}




\begin{tabular}{|c|c|c|c|c|}
\hline Variables & Type & Attribute & Name & Index specification \\
\hline $\begin{array}{l}\text { Dependent } \\
\text { variable }\end{array}$ & $\begin{array}{l}\text { Industries in } \\
\text { great bay areas }\end{array}$ & $\begin{array}{l}\text { Industrial } \\
\text { specialization }\end{array}$ & $\begin{array}{l}\text { Location entropy } \\
(L Q)\end{array}$ & Industrial agglomeration \\
\hline \multirow[t]{2}{*}{$\begin{array}{l}\text { Independent } \\
\text { variables }\end{array}$} & \multirow[t]{2}{*}{$\begin{array}{l}\text { High-speed rail } \\
\text { construction } \\
\text { variables }\end{array}$} & Policy attribute & $\begin{array}{l}\text { Dummy variable } \\
(H)\end{array}$ & $\begin{array}{l}\text { Regional dimension; } \\
\text { the dummy variable is } 1 \text { if } \\
\text { high-speed rail is opened } \\
\text { and } 0 \text { if otherwise }\end{array}$ \\
\hline & & Time attribute & $\begin{array}{l}\text { Dummy variable } \\
(T)\end{array}$ & $\begin{array}{l}\text { Time dimension; } \\
\text { the dummy variable is } 1 \text { if } \\
\text { high-speed rail is opened } \\
\text { and } 0 \text { if otherwise }\end{array}$ \\
\hline \multirow{4}{*}{\multicolumn{2}{|c|}{ Control variables }} & Spatial attribute & $\begin{array}{l}\text { Accessibility } \\
(A c c)\end{array}$ & $\begin{array}{l}\text { Reciprocal of average } \\
\text { traveling time }\end{array}$ \\
\hline & & Urban attribute & $\begin{array}{l}\text { Urbanization rate } \\
(U r b)\end{array}$ & $\begin{array}{l}\text { Proportion of population } \\
\text { municipal district in total } \\
\text { population of a city }\end{array}$ \\
\hline & & Economic attribute & $\begin{array}{l}\text { Foreign opening } \\
\text { level }(F d i)\end{array}$ & $\begin{array}{l}\text { Actual use of foreign } \\
\text { investment at the current } \\
\text { year (10,000 dollars) }\end{array}$ \\
\hline & & Social attribute & $\begin{array}{l}\text { Degree of } \\
\text { government } \\
\text { intervention } \\
(\text { Gov })\end{array}$ & $\begin{array}{l}\text { Proportion of fiscal } \\
\text { expenditure in GDP }\end{array}$ \\
\hline
\end{tabular}

adaptation problem of the model, the quantile regression model of fixed effect panel data is directly applied for estimation.

\subsection{Variables}

In this study, industrial agglomeration $L Q_{i t}$ is chosen as the dependent variable. $L Q_{I}-L Q_{8}$ refer to location entropies of manufacturing industry; wholesale and retail industry; accommodation and catering industry; financial industry; real estate industry; renting and business service industry; transportation, warehousing, and post industry; and scientific research technological services and geological prospecting industry. Comprehensive effect of industrial agglomeration $\left(H_{i t} T_{i t}\right)$, accessibility $\left(A c c_{i t}\right)$, urbanization level $\left(U r b_{i i}\right)$, human capital $\left(H_{u m_{i}}\right)$, foreign investment level $\left(F d i_{i}\right)$, and degree of government intervention $\left(G_{i} v_{i t}\right)$ are included as independent variables. All variables are listed in Tab. 2.

\subsection{Data Sources}

The time span of the sample data used in this study is 2005-2016. Data are collected from China City Statistical Yearbook, China Population and Employment Statistical Yearbook, and China Statistical Yearbook of different provinces during 2006-2017. The average traveling time of high-speed rail is gained from the National Passenger Train Schedule and China Railway Timetable website (https://www.12306.cn). Industrial data are selected according to the standards of National Economic Industrial Classification in China (GB/T4754-2011). Wholesale and retail industry, accommodation and catering industry, financial industry, real estate industry, and renting and business service industry are divided as refined industries of business service industries. Transportation, warehousing, and post industry and scientific research technological services and geological prospecting industry are used as refined industries of non-business service industries. 
In this study, a total of 79 cities in the CircumBohai Great Bay Area, Circum-Yangtze Estuary Great Bay Area, and Guangdong-Hong KongMacao Greater Bay Area are used as sample data. Core areas of the Circum-Bohai Great Bay Area were composed of all prefecturelevel and higher cities in Beijing-Tianjin-Hebei urban agglomeration, urban agglomeration in Central-South Liaoning Province, and urban agglomeration of Shandong Peninsula. Core cities in the Circum-Yangtze Estuary Great Bay Area are composed of Shanghai, Ningbo, Zhoushan, Hangzhou, Shaoxing, Jiaxing, Suzhou, Huzhou, and Natong. In addition, other Yangtze River Delta cities close to the bay area are considered hinterland cities (26 prefecture level cities). Guangzhou, Foshan, Zhaoqing, Shenzhen, Dongwan, Huizhou, Zhuhai, Zhongshan, and Jiangmen in Pearl River Delta, Hong Kong, and Macao are all covered by Guangdong-Hong Kong-Macao Greater Bay Area. The Pearl River Delta urban agglomeration is composed of significantly different administrative systems and economic systems with Hong Kong and Macao. Thus, this study mainly investigates the effects of high-speed rail construction on industrial agglomeration of Guangdong-Hong KongMacao Greater Bay Area, which is composed of nine cities.

\section{Results Analysis}

\subsection{Effects of High-speed Rail}

\section{on Industrial Agglomeration: Three Great Bay Areas}

Generally, high-speed rail construction causes significant changes to industrial layout in cities along high-speed rail networks. Effects of high-speed rail on industrial agglomeration in three great bay areas were investigated using DID model based on panel data during 2005-2016. An empirical test was also carried out. Results are shown in Tab. 3. First, in the Circum-Bohai Great Bay Area, the regression coefficient of the effects of high-speed rail on manufacturing industry is approximately -0.122 and is significant on the $10 \%$ level. This finding indicates that manufacturing industry expands uniformly due to the opening of high-speed rail. The regression coefficient of the effects of highspeed rail on real estate industry is negative and passes the significance test. This finding is manifested by the diffusion effect of cities with high-speed rail on cities without high-speed rail. Thus, the equilibrium effect of industrial layout is enhanced continuously due to high-speed rail construction. Second, in the Circum-Yangtze Estuary Great Bay Area, high-speed rail exerts positive impacts on industrial agglomeration of manufacturing, financial, real estate, and scientific research technological services and geological prospecting industries. The estimation coefficients of the effects of high-speed rail on wholesale and retail, accommodation and catering, and transportation industries are negative. This finding exhibits that the operation of high-speed railway promotes the formation of the diffusion effect of these two industries Third, in the Guangdong-Hong Kong-Macao Greater Bay Area, the estimation coefficients of the effects of high-speed rail on manufacturing, accommodation and catering, financial, renting, and transportation industries are negative. This finding exhibits certain diffusion effects of highspeed rail on above industries. In sum, highspeed rail is beneficial to realize equilibrium development among these three great bay areas.

Moreover, a correlation analysis on industrial agglomeration of manufacturing industry is carried out. The analysis concludes that $H T$ coefficients of the Circum-Bohai Great Bay Area, the Circum-Yangtze Estuary Great Bay Area, and the Guangdong-Hong KongMacao Greater Bay Area are $-0.122,0.106$, and -0.156 , respectively. High-speed rail causes negative effects on the Circum-Bohai Great Bay Area and the Guangdong-Hong Kong-Macao Greater Bay Area. These negative effects passes the significance test, indicating that highspeed rail construction causes diffusion effects on manufacturing industry in these two bay areas. Thus, the market range of manufacturing industry has expanded due to the improvements in accessibility. This improvement significantly promotes development of manufacturing industry in other regions. Furthermore, the improvement in accessibility is beneficial for diffusion of manufacturing industry in the Yangtze River Delta Great Bay Area.

According to correlation analysis of business service industries, the connection of high-speed rail corridors not only increases accessibility but also instigates the development of tourism industry and relevant industries. The developed high-speed rail corridor reduces time cost and expenses of tourists, and thus 


\begin{tabular}{|c|c|c|c|c|c|c|c|}
\hline $\begin{array}{ll}\text { Tab. 3: } & \text { Empir } \\
\text { in thre }\end{array}$ & $\begin{array}{l}\text { al result } \\
\text { great be }\end{array}$ & $\begin{array}{l}\text { the effec } \\
\text { reas }\end{array}$ & of hic & eed $r$ & nd & agglor & ion \\
\hline \multirow[t]{2}{*}{ Variables } & \multirow[t]{2}{*}{$\begin{array}{l}\text { Location } \\
\text { entropy }\end{array}$} & \multicolumn{2}{|c|}{$\begin{array}{l}\text { Circum-Bohai } \\
\text { Great Bay Area }\end{array}$} & \multicolumn{2}{|c|}{$\begin{array}{c}\text { Circum-Yangtze } \\
\text { Estuary } \\
\text { Great Bay Area }\end{array}$} & \multicolumn{2}{|c|}{$\begin{array}{c}\text { Guangdong- } \\
\text { Hong Kong-Macao } \\
\text { Greater Bay Area }\end{array}$} \\
\hline & & $H T$ & $R^{2}$ & $H T$ & $R^{2}$ & $H T$ & $R^{2}$ \\
\hline $\begin{array}{l}\text { Manufacturing } \\
\text { industry }\end{array}$ & $L Q_{1}$ & $\begin{array}{l}-0.122^{*} \\
(0.067)\end{array}$ & 0.603 & $\begin{array}{c}0.106 \\
(0.093)\end{array}$ & 0.555 & $\begin{array}{l}-0.156^{* *} \\
(0.053)\end{array}$ & 0.421 \\
\hline \multirow[t]{5}{*}{$\begin{array}{l}\text { Business service } \\
\text { industry }\end{array}$} & $L Q_{2}$ & $\begin{array}{l}-0.037 \\
(0.092)\end{array}$ & 0.438 & $\begin{array}{l}-0.091 \\
(0.166)\end{array}$ & 0.444 & $\begin{array}{l}-0.129 \\
(0.126)\end{array}$ & 0.186 \\
\hline & $L Q_{3}$ & $\begin{array}{l}-0.121 \\
(0.104)\end{array}$ & 0.509 & $\begin{array}{c}-0.252 \\
(0.213)\end{array}$ & 0.357 & $\begin{array}{l}-0.314^{* *} \\
(0.120)\end{array}$ & 0.548 \\
\hline & $L Q_{4}$ & $\begin{array}{c}0.063 \\
(0.109)\end{array}$ & 0.291 & $\begin{array}{l}0.121^{*} \\
(0.097)\end{array}$ & 0.388 & $\begin{array}{l}-0.720^{* * *} \\
(0.203)\end{array}$ & 0.422 \\
\hline & $L Q_{5}$ & $\begin{array}{l}-0.284^{* * *} \\
(0.101)\end{array}$ & 0.097 & $\begin{array}{l}0.115 \\
(0.119)\end{array}$ & 0.419 & $\begin{array}{l}-0.175 \\
(0.131)\end{array}$ & 0.281 \\
\hline & $L Q_{6}$ & $\begin{array}{l}-0.170 \\
(0.174) \\
\end{array}$ & 0.122 & $\begin{array}{c}0.088 \\
(0.111) \\
\end{array}$ & 0.279 & $\begin{array}{r}-0.182^{*} \\
(0.086) \\
\end{array}$ & 0.664 \\
\hline \multirow[t]{2}{*}{$\begin{array}{l}\text { Non-business } \\
\text { service industry }\end{array}$} & $L Q_{7}$ & $\begin{array}{l}-0.015 \\
(0.097)\end{array}$ & 0.533 & $\begin{array}{l}-0.050 \\
(0.138)\end{array}$ & 0.135 & $\begin{array}{l}-0.200^{\star *} \\
(0.083)\end{array}$ & 0.448 \\
\hline & $L Q_{8}$ & $\begin{array}{l}-0.118 \\
(0.098)\end{array}$ & 0.145 & $\begin{array}{c}0.093 \\
(0.091)\end{array}$ & 0.466 & $\begin{array}{c}-0.170 \\
(0.101)\end{array}$ & 0.559 \\
\hline
\end{tabular}

Source: own

Note: Numbers in brackets represent standard errors. ${ }^{* *},{ }^{* *}$, and * denote passing the test on $1 \%, 5 \%$, and $10 \%$ significance levels.

prompts the development mode of point-axis tourism space. In this case, tourism industry can drive development of wholesale and retail industry, accommodation and catering industry, and renting and business services $\left(L Q_{2}, L Q_{3}\right.$ and $L Q_{6}$ ) within certain spatial range. Given the construction of high-speed rail project, the traveling time from Beijing to Shenyang and Dalian is shortened by at least three hours; the traveling time from Beijing to Jinan is less than two hours; and the traveling time from Beijing to Qingdao is shortened by half. Moreover, the traveling time from Beijing to Shanghai and Hangzhou is controlled at approximately five hours at the least. Accessibility of cities along high-speed rail is significantly improved. Highspeed rail saves approximately two-thirds of the travelling time compared with the previous passenger transportation on land. Specifically, the equilibrium development of financial industry between the Circum-Bohai Great Bay Area and the Circum-Yangtze Estuary Great Bay Area has been significantly facilitated by increasing the accessibility. Moreover, financial industry in the Guangdong-Hong KongMacao Greater Bay Area has diffused after the opening of high-speed railway. In terms of real estate, the operation of high-speed rail and the improvement in accessibility have significant negative effects on the agglomeration of the real estate industry in all three great bay areas. These negative effects may be attributed to the crowding effect of big cities, which led to the diffusion effect of the real estate industry along high-speed rail cities.

For non-business service industries, the coefficient of the effect of high-speed rail on transportation, warehousing, and post industry $\left(L Q_{7}\right)$ is -0.200 . Thus, it passes the significance test. Some diffusion effect was also detected. High-speed rail also may redistribute employment resources in non-business service industry. Given the increase in radiation range of high-speed rail network, labor forces in transportation, warehousing, and post industry in cities with high-speed rail in the GuangdongHong Kong-Macao Greater Bay Area are diffused to cities without high-speed rail. 


\subsection{Analysis of the Evaluation Results of the Circum-Bohai Great Bay Area}

The Cooperative Development Outline for Circum-Bohai Sea Region was printed by the Development and Reform Commission of China on October 12, 2015. This development outline covers Beijing, Tianjin, Hebei, Shandong, Liaoning, Shanxi, and Inner Mongolia into the Circum-Bohai Sea Region. Circum-Bohai Great Bay Area is suggested to be developed into an economic growth engine and an all-round open portal. High-speed rail network strengthens spatial ties and expands the coverage of functional organizations in the Circum-Bohai Sea Region, which are in favor of the flows of local talents, industries, and technological factors. These benefits caused by high-speed rail network have laid a good foundation to accelerate the regional construction and the development of bay area economy, making it one of the national first-class great bay areas. Column 1 in Tab. 4 shows that the construction of high-speed railway has significant diffusion effect on manufacturing and real estate industries. Given that high-speed rail construction is viewed as an "external impact," it may increase land use demands and trigger changes in industrial layout. Moreover, urban developers increase construction activities surrounding high-speed railway stations, forming a scene of "city construction based on high-speed rail." This effect indicates that industrial layout expands as a result of the improvement in accessibility, which significantly promotes industrial development in other regions.

According to the comparison of different quantiles, effects of high-speed rail on industrial agglomeration in cities along the great bay areas are investigated by panel quantile regression. Based on the results in Columns 2-4 in Tab. 4, the effects of high-speed rail on manufacturing, business service, and nonbusiness service industries varies in different cities along the great bay areas under different quantiles. First, operation of high-speed rail and manufacturing industry: operation of high-speed rail is negatively correlated with manufacturing industrial agglomeration under different quantiles, given that manufacturing industry in coastal cities has gradually diffused to inland cities after the opening of highspeed rail. Second, operation of high-speed rail and business service industry: when high- speed rail is operated at different quantiles, industrial agglomeration levels of wholesale and retail, real estate, and renting industries are negatively correlated with high-speed rail in the Circum-Bohai Great Bay Area. Moreover, the absolute value of estimation coefficient gradually increases. This finding reveals that the diffusion effect of high-speed rail on these three industries is strengthened when the industrial agglomeration level is higher. High-speed rail has lowered logistics and transaction costs, accelerated element flows across different cities, and promoted overflow of positive externality of cities. As a result, business service industry achieved a balanced development. Third, operation of high-speed rail and non-business service industry: when highspeed rail is operated at different quantiles, transportation, warehousing, and post industry and scientific research technological services and geological prospecting industry are influenced to different extents. The diffusion effect of transportation industry declines at first, but then increases with the increase of industrial agglomeration level. This finding implies that the strongest diffusion effect is achieved under relatively low and high industrial agglomeration levels. Urban development may become saturated to some extent. A limited space exists for industrial agglomeration and industries diffusion to surrounding areas. The scientific research technological services and geological prospecting industrial agglomeration increases at first, but then decreases to some extent. Diffusion of this industry has decelerated after high-speed rail reached a certain level.

According to the comparison of different city sizes, the Circum-Bohai Great Bay Area has adapted industries from the capital when the high-speed rail network is gradually expanding. However, loose ties exist among urban agglomerations in the Circum-Bohai Great Bay Area, which is caused by long-term separation. Moreover, unreasonable division is observed in labor and serious industrial homogenization among different cities. Different cities in the Circum-Bohai Great Bay Area has still relied on manufacturing industry and had ambiguous division of labor and orientation, which are also resulted in fierce fight for hinterlands among different cities. The effects of highspeed rail on cities are related with different city sizes. Moreover, high-speed rail promotes agglomeration of wholesale and retail, real 


\begin{tabular}{|c|c|c|c|c|c|c|c|}
\hline \multirow{3}{*}{ Variables } & \multicolumn{7}{|c|}{$\begin{array}{l}\text { Evaluation results of the effects of high-speed rail construction on industrial } \\
\text { agglomeration in the Circum-Bohai Great Bay Area }\end{array}$} \\
\hline & \multirow{2}{*}{$\begin{array}{c}\text { Full } \\
\text { sample }\end{array}$} & \multicolumn{3}{|c|}{ Comparison based on quantiles } & \multicolumn{3}{|c|}{ Comparison based on city sizes } \\
\hline & & QR_30 & QR_60 & QR_90 & Big & Middle & Small \\
\hline$L Q_{1}$ & $\begin{array}{r}-0.122^{*} \\
(0.067)\end{array}$ & $\begin{array}{l}-0.062 \\
(0.055)\end{array}$ & $\begin{array}{l}-0.076 \\
(0.082)\end{array}$ & $\begin{array}{l}0.037 \\
(0.051)\end{array}$ & $\begin{array}{l}-0.103 \\
(0.073)\end{array}$ & $\begin{array}{l}-0.156 \\
(0.103)\end{array}$ & $\begin{array}{l}-0.314 \\
(0.269)\end{array}$ \\
\hline$L Q_{2}$ & $\begin{array}{c}-0.0375 \\
(0.091)\end{array}$ & $\begin{array}{l}-0.346^{* * *} \\
(0.074)\end{array}$ & $\begin{array}{l}-0.405^{* * *} \\
(0.041)\end{array}$ & $\begin{array}{l}-0.406^{* * *} \\
(0.055)\end{array}$ & $\begin{array}{c}0.002 \\
(0.113)\end{array}$ & $\begin{array}{r}-0.274^{*} \\
(0.152)\end{array}$ & $\begin{array}{r}1.170^{*} \\
(0.534)\end{array}$ \\
\hline$L Q_{3}$ & $\begin{array}{c}-0.121 \\
(0.104)\end{array}$ & $\begin{array}{l}-0.342^{* * *} \\
(0.081)\end{array}$ & $\begin{array}{l}-0.374^{* * *} \\
(0.067)\end{array}$ & $\begin{array}{l}-0.344^{* * *} \\
(0.067)\end{array}$ & $\begin{array}{c}-0.048 \\
(0.128)\end{array}$ & $\begin{array}{c}-0.244 \\
(0.211)\end{array}$ & $\begin{array}{c}-0.179 \\
(0.746)\end{array}$ \\
\hline$L Q_{4}$ & $\begin{array}{c}0.064 \\
(0.109)\end{array}$ & $\begin{array}{l}-0.506^{* * *} \\
(0.088)\end{array}$ & $\begin{array}{l}-0.318^{* * *} \\
(0.062)\end{array}$ & $\begin{array}{l}-0.294^{* * *} \\
(0.066)\end{array}$ & $\begin{array}{c}0.081 \\
(0.153)\end{array}$ & $\begin{array}{c}0.076 \\
(0.134)\end{array}$ & $\begin{array}{c}0.009 \\
(0.490)\end{array}$ \\
\hline$L Q_{5}$ & $\begin{array}{l}-0.284^{* * *} \\
(0.101)\end{array}$ & $\begin{array}{c}-0.042 \\
(0.054)\end{array}$ & $\begin{array}{l}-0.199^{\star * *} \\
(0.064)\end{array}$ & $\begin{array}{l}-0.377^{\star * *} \\
(0.082)\end{array}$ & $\begin{array}{c}-0.256^{* *} \\
(0.116)\end{array}$ & $\begin{array}{c}-0.234 \\
(0.243)\end{array}$ & $\begin{array}{c}0.398^{* *} \\
(0.126)\end{array}$ \\
\hline$L Q_{6}$ & $\begin{array}{c}-0.170 \\
(0.174) \\
\end{array}$ & $\begin{array}{l}-0.298^{\star * *} \\
(0.053)\end{array}$ & $\begin{array}{l}-0.493^{* * *} \\
(0.070)\end{array}$ & $\begin{array}{l}-0.707^{* * *} \\
(0.152)\end{array}$ & $\begin{array}{c}-0.290^{* *} \\
(0.121)\end{array}$ & $\begin{array}{c}0.288 \\
(0.563)\end{array}$ & $\begin{array}{c}-1.053 \\
(1.068)\end{array}$ \\
\hline$L Q_{7}$ & $\begin{array}{c}-0.015 \\
(0.097)\end{array}$ & $\begin{array}{l}-0.410^{* * *} \\
(0.109)\end{array}$ & $\begin{array}{l}-0.280^{* * *} \\
(0.092)\end{array}$ & $\begin{array}{c}-0.306^{* *} \\
(0.119)\end{array}$ & $\begin{array}{c}-0.045 \\
(0.091)\end{array}$ & $\begin{array}{c}-0.033 \\
(0.231)\end{array}$ & $\begin{array}{c}0.371^{*} \\
(0.165)\end{array}$ \\
\hline$L Q_{8}$ & $\begin{array}{c}-0.118 \\
(0.098)\end{array}$ & $\begin{array}{c}-0.289^{* *} \\
(0.123)\end{array}$ & $\begin{array}{l}-0.447^{* * *} \\
(0.096)\end{array}$ & $\begin{array}{l}-0.327^{* *} \\
(0.158)\end{array}$ & $\begin{array}{c}0.013 \\
(0.089)\end{array}$ & $\begin{array}{c}-0.508^{\star *} \\
(0.225)\end{array}$ & $\begin{array}{c}-0.146 \\
(0.139)\end{array}$ \\
\hline
\end{tabular}

Source: own

Note: Numbers in brackets represent standard errors. ${ }^{* *},{ }^{* *}$, and * denote passing the test on $1 \%, 5 \%$, and $10 \%$ significance levels.

estate, and transportation, warehousing, and post industries to small cities.

\subsection{Analysis of the Evaluation Results of the Circum-Yangtze Estuary Great Bay Area}

On May 11, 2016, the State Council passed the Development Plan of City Agglomeration in Yangtze River Delta. City agglomeration in the Yangtze River Delta has strong international competitiveness and owns global important modern service industries and advanced manufacturing industrial center. The CircumYangtze Estuary Great Bay Area (or known as the Yangtze River Delta) is an economic region with the highest economic growth rate, the largest economic aggregate, and the strongest international competitiveness in China at present. A new industrial development pattern centered at advanced manufacturing industry and supported by modern service industry has been formed. Shanghai-Ningbo high-speed railway, Shanghai-Hangzhou high-speed railway, and Ningbo-Hangzhou high-speed railway are located in the Circum-Yangtze Estuary Great
Bay Area. In addition, high-speed railways going to cities located outside the great bay area exist, including Beijing-Shanghai high-speed railway, Shanghai-Wuhan-Chengdu high-speed railway, Hangzhou-Changsha high-speed railway, and Shanghai-Shenzhen high-speed railway. Accordingly, the perfect high-speed rail network and good regional environment will be conducive to the adjustment of industrial spatial layout.

According to the comparison of different quantiles, the estimation coefficient of the effects of high-speed rail on manufacturing industry changes from negative to positive. Given a low industrial agglomeration level, manufacturing industry has significantly diffused after high-speed rail construction. However, such diffusion effect disappears gradually as industrial agglomeration level increased. Given a high industrial agglomeration level, manufacturing industry presents an agglomeration effect. Therefore, manufacturing industry has experienced three stages, namely, diffusion accelerating stage, diffusion weakening stage, and agglomeration weakening stage. When the quantile is low, high-speed rail exhibits agglomeration effects on financial and real estate industries. Given 
the continuous perfection of high-speed rail network, industries diffuse continuously and an equilibrium development is realized.

According to the comparison of different city sizes, the coefficients of the effects of highspeed rail on manufacturing industry in big, middle, and small cities are $-0.009,0.226$, and 3.681 , respectively. This finding proves that the opening of high-speed rail force manufacturing industry to migrate from big cities to middle and small cities as a response to the migration of workers in traditional manufacturing industry along the high-speed rail corridor. The employment structure of manufacturing industry changes accordingly. Operation of high-speed rail is beneficial for agglomeration of financial and transportation industries to small cities, thus gradually narrowing the gap among small cities and increasing division of labor among different regions. Due to the opening of four high-speed railways (Shanghai-Ningbo, Shanghai-Hangzhou, Ningbo-Hangzhou, and Beijing-Shanghai), the Circum-Yangtze Estuary Great Bay Area has owned the most perfect high-speed rail network in China at present.
Thus, high-speed rail network accelerates the economic integration in the Circum-Yangtze Estuary Region and is conducive to form an ordered industrial level system.

\subsection{Analysis of the Evaluation Results of the Guangdong-Hong Kong- Macao Greater Bay Area}

In 2017, the Central Economic Working Conference emphasized the scientific planning for construction of the Guangdong-Hong Kong-Macao Greater Bay Area. A ShenzhenHong Kong-Macao technological innovation corridor is connected along high-speed rail. The urban agglomeration in Pearl River Delta is an important component of the Guangdong-Hong Kong-Macao Greater Bay Area. The process of promoting integrated development of industry and space may affect construction progress of the Guangdong-Hong Kong-Macao Greater Bay Area to a large extent. The construction of a traffic network will enhance networking trend in the Guangdong-Hong Kong-Macao Greater Bay Area, strengthen the tie between the east and west banks of the Pearl River, and

\begin{tabular}{|c|c|c|c|c|c|c|c|}
\hline \multirow{3}{*}{ Variables } & \multicolumn{7}{|c|}{$\begin{array}{l}\text { Evaluation results of the effects of high-speed rail construction on industrial } \\
\text { agglomeration in the Circum-Yangtze Estuary Great Bay Area }\end{array}$} \\
\hline & \multirow{2}{*}{$\begin{array}{c}\text { Full } \\
\text { sample }\end{array}$} & \multicolumn{3}{|c|}{ Comparison based on quantiles } & \multicolumn{3}{|c|}{ Comparison based on city sizes } \\
\hline & & QR_30 & QR_60 & QR_90 & Big & Middle & Small \\
\hline$L Q_{1}$ & $\begin{array}{c}0.106 \\
(0.093)\end{array}$ & $\begin{array}{l}-0.270^{\star * *} \\
(0.097)\end{array}$ & $\begin{array}{c}-0.157 \\
(0.119)\end{array}$ & $\begin{array}{c}0.022 \\
(0.080)\end{array}$ & $\begin{array}{c}-0.009 \\
(0.085)\end{array}$ & $\begin{array}{c}0.226 \\
(0.177)\end{array}$ & $\begin{array}{l}3.681^{* *} \\
(1.180)\end{array}$ \\
\hline$L Q_{2}$ & $\begin{array}{c}-0.092 \\
(0.166)\end{array}$ & $\begin{array}{c}0.083 \\
(0.164)\end{array}$ & $\begin{array}{c}-0.072 \\
(0.147)\end{array}$ & $\begin{array}{c}0.043 \\
(0.099)\end{array}$ & $\begin{array}{c}0.204^{* *} \\
(0.088)\end{array}$ & $\begin{array}{c}-0.339 \\
(0.339)\end{array}$ & $\begin{array}{c}-0.011 \\
(2.405)\end{array}$ \\
\hline$L Q_{3}$ & $\begin{array}{c}-0.252 \\
(0.213)\end{array}$ & $\begin{array}{r}-0.410^{*} \\
(0.232)\end{array}$ & $\begin{array}{l}-0.399^{* * *} \\
(0.149)\end{array}$ & $\begin{array}{c}-0.157 \\
(0.231)\end{array}$ & $\begin{array}{c}0.052 \\
(0.125)\end{array}$ & $\begin{array}{c}-0.524 \\
(0.431)\end{array}$ & $\begin{array}{c}6.573 \\
(3.719)\end{array}$ \\
\hline$L Q_{4}$ & $\begin{array}{c}0.121^{*} \\
(0.097)\end{array}$ & $\begin{array}{l}0.271^{* * *} \\
(0.071)\end{array}$ & $\begin{array}{c}-0.026 \\
(0.103)\end{array}$ & $\begin{array}{c}0.006 \\
(0.071)\end{array}$ & $\begin{array}{c}0.005 \\
(0.083)\end{array}$ & $\begin{array}{c}0.352 \\
(0.262)\end{array}$ & $\begin{array}{r}4.482^{*} \\
(1.867)\end{array}$ \\
\hline$L Q_{5}$ & $\begin{array}{c}0.115 \\
(0.119)\end{array}$ & $\begin{array}{c}0.190^{*} \\
(0.106)\end{array}$ & $\begin{array}{c}-0.046 \\
(0.114)\end{array}$ & $\begin{array}{c}-0.119 \\
(0.176)\end{array}$ & $\begin{array}{c}0.064 \\
(0.115)\end{array}$ & $\begin{array}{c}0.192 \\
(0.239)\end{array}$ & $\begin{array}{c}4.790 \\
(4.000)\end{array}$ \\
\hline$L Q_{6}$ & $\begin{array}{c}0.088 \\
(0.111) \\
\end{array}$ & $\begin{array}{c}-0.084 \\
(0.108)\end{array}$ & $\begin{array}{c}-0.037 \\
(0.189)\end{array}$ & $\begin{array}{c}-0.244^{* *} \\
(0.119)\end{array}$ & $\begin{array}{c}0.105 \\
(0.090)\end{array}$ & $\begin{array}{c}0.203 \\
(0.120)\end{array}$ & $\begin{array}{c}1.117 \\
(6.903)\end{array}$ \\
\hline$L Q_{7}$ & $\begin{array}{c}-0.051 \\
(0.138)\end{array}$ & $\begin{array}{l}-0.389^{* * *} \\
(0.089)\end{array}$ & $\begin{array}{l}-0.315^{\star \star *} \\
(0.111)\end{array}$ & $\begin{array}{c}-0.327 \\
(0.200)\end{array}$ & $\begin{array}{c}-0.013 \\
(0.078)\end{array}$ & $\begin{array}{c}-0.119 \\
(0.393)\end{array}$ & $\begin{array}{l}8.354^{* * *} \\
(0.546)\end{array}$ \\
\hline$L Q_{8}$ & $\begin{array}{c}0.093 \\
(0.091)\end{array}$ & $\begin{array}{c}0.223 \\
(0.195)\end{array}$ & $\begin{array}{c}0.224 \\
(0.176)\end{array}$ & $\begin{array}{c}-0.036 \\
(0.177)\end{array}$ & $\begin{array}{c}0.016 \\
(0.098)\end{array}$ & $\begin{array}{c}0.149 \\
(0.158)\end{array}$ & $\begin{array}{c}2.621 \\
(1.777)\end{array}$ \\
\hline
\end{tabular}


form a relatively equilibrium multipolar network pattern in the area.

According to the comparison of different quantiles, the estimated level of high-speed rail operation on manufacturing agglomeration changes from significant to non-significant. When the level of industrial agglomeration is low, high-speed rail has a significant diffusion state on manufacturing industry. Given the improvement of industrial agglomeration level, the significance of diffusion effect is decreased. This finding shows that the manufacturing industry in Guangdong-Hong Kong-Macao Bay Area changes from diffusion acceleration to diffusion weakening. Whether the quantile is at a low or a high level, the operation of high-speed rail has a clustering effect on the wholesale and retail and accommodation and catering industries. The operation of high-speed rail has played a role in promoting the agglomeration of service industry in Guangdong, Hong Kong, and Macao.

According to the comparison of different city sizes, high-speed rail facilitates development of financial industry. For big and small cities, high-speed rail is conducive to diffusion of financial industry. By contrast, financial industrial agglomeration is formed in middle cities after the opening of high-speed rail. With the rapid economic growth in the bay area, financial industry, as one of the important producer services, maintains a stable rapid growth. The strength of financial industry increases continuously. According to the geological advantageous estuary and bay, the Guangdong-Hong Kong-Macao Greater Bay Area constructs a smooth channel for resource exchange between cities' hinterlands and the outside world. This resource exchange brings a rapid development and economic prosperity in this bay area. Accordingly, high-speed rail, as an important reform of traffic technology, will shrink economic gaps of different cities in the Guangdong-Hong Kong-Macao Greater Bay Area and thereby realize an equilibrium development.

\subsection{Robustness Test}

With reference to relevant studies (Brouwer et al., 2014), the policy is implemented three

\begin{tabular}{ccc|c|c|c|c|c|c}
\multirow{2}{*}{ Tab. 6: } & Evaluation results of the effects of high-speed rail construction on industrial \\
& agglomeration in the Guangdong-HongKong-Macao Greater Bay Area \\
\hline \multirow{2}{*}{ Variables } & Full & \multicolumn{2}{c}{ Comparison based on quantiles } & \multicolumn{2}{c}{ Comparison based on city sizes } \\
\cline { 3 - 8 } & sample & QR_30 & QR_60 & QR_90 & Big & \multicolumn{2}{c}{ Middle } & Small \\
\hline \multirow{2}{*}{$L Q_{1}$} & $-0.156^{* *}$ & $-0.122^{* * *}$ & -0.035 & -0.121 & -0.225 & 0.041 & -0.034 \\
& $(0.054)$ & $(0.039)$ & $(0.058)$ & $(0.081)$ & $(0.125)$ & $(0.093)$ & $(0.065)$ \\
\hline \multirow{2}{*}{$L Q_{2}$} & -0.129 & $-0.344^{* *}$ & $-0.494^{* * *}$ & $-0.582^{* * *}$ & -0.221 & 0.618 & 0.019 \\
& $(0.126)$ & $(0.155)$ & $(0.166)$ & $(0.141)$ & $(0.117)$ & $(0.561)$ & $(0.403)$ \\
\hline \multirow{2}{*}{$L Q_{3}$} & $-0.314^{* *}$ & $-0.616^{* *}$ & $-0.999^{* * *}$ & $-0.677^{* *}$ & -0.235 & 0.438 & -0.342 \\
& $(0.120)$ & $(0.249)$ & $(0.137)$ & $(0.324)$ & $(0.170)$ & $(0.608)$ & $(0.368)$ \\
\hline \multirow{2}{*}{$L Q_{4}$} & $-0.720^{* * *}$ & $-1.249^{* * *}$ & $-0.292^{*}$ & -0.138 & $-0.625^{* *}$ & 0.405 & $-0.995^{*}$ \\
& $(0.203)$ & $(0.210)$ & $(0.158)$ & $(0.103)$ & $(0.201)$ & $(0.888)$ & $(0.273)$ \\
\hline \multirow{2}{*}{$L Q_{5}$} & -0.175 & $-0.395^{*}$ & $-0.609^{* *}$ & -0.468 & -0.127 & 0.0213 & -0.301 \\
& $(0.131)$ & $(0.214)$ & $(0.256)$ & $(0.353)$ & $(0.136)$ & $(0.149)$ & $(0.179)$ \\
\hline \multirow{2}{*}{$L Q_{6}$} & $-0.182^{*}$ & -0.283 & $-0.820^{* *}$ & -0.504 & 0.012 & -0.067 & -0.421 \\
& $(0.086)$ & $(0.173)$ & $(0.346)$ & $(0.309)$ & $(0.051)$ & $(0.403)$ & $(0.204)$ \\
\hline \multirow{2}{*}{$L Q_{7}$} & $-0.200^{* *}$ & -0.269 & -0.332 & 0.023 & -0.093 & -0.191 & -0.394 \\
& $(0.083)$ & $(0.270)$ & $(0.277)$ & $(0.242)$ & $(0.080)$ & $(0.139)$ & $(0.223)$ \\
\hline \multirow{2}{*}{$L Q_{8}$} & -0.170 & -0.335 & $-0.605^{* *}$ & -0.032 & -0.093 & -0.038 & -0.087 \\
& $(0.101)$ & $(0.306)$ & $(0.284)$ & $(0.248)$ & $(0.143)$ & $(0.350)$ & $(0.133)$ \\
\hline
\end{tabular}

Source: own

Note: Numbers in brackets represent standard errors. ${ }^{* * *},{ }^{* *}$, and * denote passing the test on $1 \%, 5 \%$, and $10 \%$ significance levels. 


\section{Tab. 7: Counterfactual robustness test}

\begin{tabular}{|c|c|c|c|c|c|c|c|}
\hline \multirow[t]{2}{*}{ Variables } & \multirow{2}{*}{$\begin{array}{l}\text { Location } \\
\text { entropy }\end{array}$} & \multicolumn{2}{|c|}{$\begin{array}{c}\text { Circum-Bohai Great Bay } \\
\text { Area }\end{array}$} & \multicolumn{2}{|c|}{$\begin{array}{c}\text { Circum-Yangtze Estuary } \\
\text { Great Bay Area }\end{array}$} & \multicolumn{2}{|c|}{$\begin{array}{l}\text { Guangdong-Hong Kong- } \\
\text { Macao Greater Bay Area }\end{array}$} \\
\hline & & $H T$ & $H T^{\prime}$ & $H T$ & $H T^{\prime}$ & $H T$ & $H T^{\prime}$ \\
\hline $\begin{array}{l}\text { Manufacturing } \\
\text { industry }\end{array}$ & $L Q_{1}$ & $\begin{array}{l}-0.122^{*} \\
(0.067)\end{array}$ & $\begin{array}{l}-0.002 \\
(0.0482)\end{array}$ & $\begin{array}{l}0.106 \\
(0.093)\end{array}$ & $\begin{array}{l}-0.120 \\
(0.089)\end{array}$ & $\begin{array}{l}-0.156^{* *} \\
(0.053)\end{array}$ & $\begin{array}{l}-0.070 \\
(0.038)\end{array}$ \\
\hline \multirow{5}{*}{$\begin{array}{l}\text { Business } \\
\text { service } \\
\text { industry }\end{array}$} & $L Q_{2}$ & $\begin{array}{l}-0.037 \\
(0.092)\end{array}$ & $\begin{array}{l}-0.074 \\
(0.078)\end{array}$ & $\begin{array}{l}-0.091 \\
(0.166)\end{array}$ & $\begin{array}{l}-0.239^{* *} \\
(0.088)\end{array}$ & $\begin{array}{l}-0.129 \\
(0.126)\end{array}$ & $\begin{aligned}-0.239^{*} \\
(0.108)\end{aligned}$ \\
\hline & $L Q_{3}$ & $\begin{array}{l}-0.121 \\
(0.104)\end{array}$ & $\begin{array}{l}-0.094 \\
(0.069)\end{array}$ & $\begin{array}{l}-0.252 \\
(0.213)\end{array}$ & $\begin{array}{l}-0.379^{* *} \\
(0.139)\end{array}$ & $\begin{array}{l}-0.314^{* *} \\
(0.120)\end{array}$ & $\begin{array}{l}-0.320^{* * *} \\
(0.084)\end{array}$ \\
\hline & $L Q_{4}$ & $\begin{array}{l}0.063 \\
(0.109)\end{array}$ & $\begin{array}{l}-0.098^{*} \\
(0.052)\end{array}$ & $\begin{array}{l}0.121^{*} \\
(0.097)\end{array}$ & $\begin{array}{l}-0.136 \\
(0.105)\end{array}$ & $\begin{array}{l}-0.720^{* \star \star} \\
(0.203)\end{array}$ & $\begin{array}{l}-0.214 \\
(0.166)\end{array}$ \\
\hline & $L Q_{5}$ & $\begin{array}{l}-0.284^{* * *} \\
(0.101)\end{array}$ & $\begin{array}{l}-0.061 \\
(0.062)\end{array}$ & $\begin{array}{c}0.115 \\
(0.119)\end{array}$ & $\begin{array}{l}-0.015 \\
(0.085)\end{array}$ & $\begin{array}{l}-0.175 \\
(0.131)\end{array}$ & $\begin{array}{l}-0.144 \\
(0.084)\end{array}$ \\
\hline & $L Q_{6}$ & $\begin{array}{l}-0.170 \\
(0.174)\end{array}$ & $\begin{array}{l}-0.042 \\
(0.108)\end{array}$ & $\begin{array}{l}0.088 \\
(0.111)\end{array}$ & $\begin{array}{l}-0.250^{* *} \\
(0.097)\end{array}$ & $\begin{array}{l}-0.182^{*} \\
(0.086)\end{array}$ & $\begin{array}{l}-0.142 \\
(0.149)\end{array}$ \\
\hline \multirow{2}{*}{$\begin{array}{l}\text { Non-business } \\
\text { service } \\
\text { industry }\end{array}$} & $L Q_{7}$ & $\begin{array}{l}-0.015 \\
(0.097)\end{array}$ & $\begin{array}{l}-0.040 \\
(0.052)\end{array}$ & $\begin{array}{l}-0.050 \\
(0.138)\end{array}$ & $\begin{array}{c}0.176 \\
(0.103)\end{array}$ & $\begin{array}{l}-0.200^{* *} \\
(0.083)\end{array}$ & $\begin{array}{l}-0.107 \\
(0.086)\end{array}$ \\
\hline & $L Q_{8}$ & $\begin{array}{l}-0.118 \\
(0.098)\end{array}$ & $\begin{array}{c}0.039 \\
(0.061)\end{array}$ & $\begin{array}{l}0.093 \\
(0.091)\end{array}$ & $\begin{array}{l}-0.030 \\
(0.067)\end{array}$ & $\begin{array}{l}-0.170 \\
(0.101)\end{array}$ & $\begin{array}{l}-0.107 \\
(0.089)\end{array}$ \\
\hline
\end{tabular}

Source: own

Note: Numbers in brackets represent standard errors corresponding to the testing statistical values. ${ }^{* * *},{ }^{* *}$, and * denote passing the test on $1 \%, 5 \%$, and $10 \%$ significance levels.

years earlier. The virtual time to open the highspeed rail is set in 2005 . Then, the data from 2005-2017 are tested by DID model. If the regression coefficient of cross term of highspeed rail variables is insignificant, then the sample data in this study pass the prerequisite hypothesis of DID model. This finding verifies the above basic regression results to some extent. Specifically, industrial agglomeration effects between cities with and without highspeed rail are indeed caused by high-speed rail construction. The cross term of $H T$ is the variable of the opening of high-speed rail in 2008; whereas the cross term of $H T^{\prime}$ is the variable of the opening of high-speed rail in 2005.

If the variable coefficients of opening highspeed rail three years earlier in different regions are significant, then industrial agglomeration may be attributed to other policy reforms or random factors rather than the opening of highspeed rail. If these variable coefficients are insignificant, then industrial agglomeration may be caused by high-speed rail construction. The effects of opening high-speed rail three years earlier on industrial agglomeration are shown in Columns 2, 4, and 6 in Tab. 7. The effect of high-speed rail construction on manufacturing and real estate industries in the Circum-Bohai Great Bay Area, on financial industry in the Circum-Yangtze Estuary Great Bay Area, and on manufacturing and financial industries in the Guangdong-Hong Kong-Macao Greater Bay Area are all insignificant and fail to pass the $10 \%$ significance test. Results show that industrial agglomeration is attributed to highspeed rail construction rather than other factors.

\section{Discussions}

Empirical results are further analyzed by DID model and quantile treatment effect.

First, results in Tab. 3 prove that the construction of high-speed rail can shorten the space-time distance across the bay areas, optimize the rational allocation of internal factors, and effectively promote market potential and scale effect of the bay area. This implication can be explained as follows. Highspeed rail construction generates diffusion effect to manufacturing industrial agglomeration in the Circum-Bohai Great Bay Area and the Guangdong-Hong Kong-Macao Greater Bay 
Area. The market range of manufacturing industry expands due to the increase in accessibility, which could greatly promote manufacturing industrial development in other regions. The combined traffic mode of "highspeed rail + great bay areas" is in favor of element flow and transfer across different great bay areas (Zhao et al., 2015).

Second, the effects of high-speed rail on industrial agglomeration in the Circum-Bohai Great Bay Area are shown in Tab. 4. The opening of high-speed rail is beneficial to form diffusion effect of manufacturing industry in the Circum-Bohai Great Bay Area. A perfect industrial system exists in the Circum-Bohai Great Bay Area, whereas manufacturing industry is the dominant industry in coastal regions. The opening of high-speed rail accelerates the transfer of production elements and technological innovations from coastal regions to inland areas, develops the spillover effect of manufacturing industry in coastal regions, promotes formation of the diffusion effect in manufacturing industry, realizes equilibrium configuration of production elements and industrial cooperation and division of labor (Martínez Sánchez-Mateos \& Givoni, 2012), and realizes equilibrium development of the manufacturing industry. Currently, economic development in the Circum-Bohai Sea is still dominated by manufacturing industry, accompanied with a low development level of service industry. High-speed rail can solve the disadvantages experienced in the Circum-Bohai Great Bay Area such as poor resource supply. High-speed rail can also realize cooperation and division of labor of industries and instigate development of relevant industries like tourism, finance, real estate, and so on.

Third, the effects of high-speed rail on industrial agglomeration in the CircumYangtze Estuary Great Bay Area are shown in Tab. 5. Evidently, high-speed rail instigate the development of the manufacturing and service industries. Key attentions are paid to the manufacturing, finance, and modern service industries. Although a huge urban mass exists in the Circum-Yangtze Estuary Great Bay Area, industrial development still exhibits significant regional differences. However, such differences would be gradually narrowed by the opening of high-speed rail. A perfect highspeed rail network can accelerate integrated economic development in the Circum-Yangtze
Estuary Great Bay Area (Xheneti et al., 2013). As a result, the Circum-Yangtze Estuary Great Bay Area set up an ordered industrial level system with cooperation and division of labor and dislocation development. A new pattern centered at advanced manufacturing industry and supported by modern service industry has been developed, which can promote modern service industrial development and continuous transfer and diffusion of information technology. As a result, the equilibrium development is realized (Liu \& Wu, 2017).

Fourth, effects of high-speed rail on industrial agglomeration in Guangdong-Hong KongMacao Greater Bay Area are shown in Tab. 6. Results have shown that the opening of highspeed rail promotes industrial agglomeration of the wholesale, retail, accommodation and catering industries in the Guangdong-Hong Kong-Macao Greater Bay Area. This result is consistent with the conclusion of Qin and Chai (2018). High-speed rail will cause inverse development of capitals, technologies, talents, information, and other economic elements in the Guangdong-Hong Kong-Macao Greater Bay Area along with the traditional flow. The Guangdong-Shenzhen-Hong Kong high-speed raildrivesarapiddevelopmentintourismeconomy, thus instigating the development of relevant business service industry. This development is also beneficial to form a hierarchical industrial agglomeration with resource complementarity, gradient development, and industrial association and an industrial cooperation system with complementary advantages and mutual benefits; high-speed rail also accelerates the formation of "space-industry" coupling development pattern matched with factor endowment structure and spatial organization mechanism, promotes development of modern service industry, and positively participates in division of labor in the global value chain (Vaturi et al., 2011).

\section{Conclusions}

High-speed rail construction improves accessibility and accelerates flow of elements including labor force and information. In addition, high-speed rail influences urban industrial layout by driving investment and increasing employment. In this study, an empirical test on differences of industrial agglomeration in three great bay areas is carried out based on panel data of 79 cities since the era of high-speed rail (2005-2016). 
The following conclusions can be drawn: (1) the effects of high-speed rail construction on industrial spatial layout have significant regional differences. Manufacturing and real estate industries in the Circum-Bohai Great Bay Area significantly expanded after the high-speed rail construction. Moreover, wholesale and retail, real estate, and transportation, warehousing, and post industries began to agglomerate to small cities. The effects of high-speed rail construction on financial industry in the Circum-Yangtze Estuary Great Bay Area are recognized as agglomeration effects. The highspeed rail construction promotes agglomeration of manufacturing, financial, and transportation industries to small cities. Due to high-speed rail construction, manufacturing, accommodation and catering, financial, and transportation, warehousing, and post industries in the Guangdong-Hong Kong-Macao Greater Bay Area have diffused. (2) Industrial agglomeration effect in the three great bay areas have extremely strong ordered agglomeration or diffusion paths, which is manifested by the following aspects. First, high-speed rail causes significant diffusion to industrial agglomeration under the mean significance. The effects of high-speed rail on industrial agglomeration in three study areas vary under different quantiles. Second, industrial levels are optimized from big cities to middle cities and small cities. Accordingly, this study does not only focus on the manufacturing industry but also subdivides the service industry and further explores the impact of high-speed rail on industrial agglomeration in Dawan District, deepening and supplementing the existing research review on high-speed rail.

Future studies can involve other great bay areas in China. High-speed rail improves location conditions, facilitates integration of industrial spatial structures in different bay areas, and promotes industrial transformation and development. This study ignores spatial correlation of industrial agglomeration effect. Thus, discussing the effects of high-speed rail on industrial agglomeration from the spatial perspective might be impossible. To further explore space-time variation laws caused by high-speed rail, a spatial DID model should be constructed to obtain a more robust conclusion.

Acknowledgments: This study was supported by National Social Science Foundation of China (18CJL030), Henan Philosophy and
Social Science Planning Project in China (2018BJJ013), and Humanities and Social Sciences Research Project of Henan Education Department in China (2020ZZJH042).

\section{References}

Brouwer, R., Cauchi, J., \& Verhoeven, J. (2014). Regulatory decision-making under uncertainty: Are costs proportionate to benefits when restricting dangerous chemicals on European markets? Regulatory Toxicology and Pharmacology, 68(3), 438-446. https://doi. org/10.1016/j.yrtph.2014.01.016

Cao, J., Liu, X. C., Wang, Y., \& Li, Q. (2013). Accessibility impacts of China's high-speed rail network. Journal of Transport Geography, 28, 12-21. https://doi.org/10.1016/j. jtrangeo.2012.10.008

Chen, C.-L. (2012). Reshaping Chinese space-economy through high-speed trains: Opportunities and challenges. Journal of Transport Geography, 22, 312-316. https://doi. org/10.1016/j.jtrangeo.2012.01.028

Cosido-Cobos, O. J., Salcines-Menezo, A., Loucera-Munecas, C., \& LorenzanaIban, A. (2018). Reverse engineering using photogrammetry and segmentation for industrial structures. DYNA, 93(5), 479-482. https://doi. org $/ 10.6036 / 8549$

Coto-Millán, P., Inglada, V., \& Rey, B. (2007). Effects of network economics in highspeed rail: the Spanish case. The Annals of Regional Science, 41(4), 911-925. https://doi. org/10.1007/s00168-007-0134-6

Delaplace, M., \& Dobruszkes, F. (2015). From low-cost airlines to low-cost high-speed rail? The French case. Transport Policy, 38, 73-85. https://doi.org/10.1016/j.tranpol.2014.12.006

Dobruszkes, F., Givoni, M., \& Vowles, T. (2017). Hello major airports, goodbye regional airports? Recent changes in European and US low-cost airline airport choice. Journal of Air Transport Management, 59, 50-62. https://doi. org/10.1016/j.jairtraman.2016.11.005

Givoni, M. (2006). Development and impact of the modern high-speed train: A review. Transport Reviews, 26(5), 593-611. https://doi. org/10.1080/01441640600589319

Givoni, M., \& Chen, X. (2017). Airline and railway disintegration in China: the case of shanghai Hongqiao integrated transport hub. Transportation letters, 9(4), 202-214. https://doi.org/10.1080/19427867.2016.1252877 
Hall, P. (2009). Magic carpets and seamless webs: opportunities and constraints for highspeed trains in Europe. Built Environment, 35(1), 59-69. https://doi.org/10.2148/benv.35.1.59

Henderson, J. V., \& Wang, H. G. (2007). Urbanization and city growth: The role of institutions. Regional Science and Urban Economics, 37(3), 282-313. https://doi. org/10.1016/j.regsciurbeco.2006.11.008

Huhtala, M., Kangas, M., Kaptein, M., \& Feldt, T. (2018). The shortened Corporate Ethical Virtues scale: Measurement invariance and mean differences across two occupational groups. Business Ethics: A European Review, 27(3), 238-247. https://doi.org/10.1111/beer.12184

Jiang, H. X., Cai, H. N., \& Meng, X. C. (2017). Research of effects of high-speed rail on industrial structures in cities in China. Human Geography, 2017(5), 132-138. https://doi. org/10.13959/j.issn.1003-2398.2017.05.019

Karolys, B., Llanes-Cedeño, E., Vega, W., Cevallos, S., \& Rocha-Hoyos, J. (2019). Effect of injection parameters and emission characteristics in a common-rail direct injection diesel engine in height conditions: A review. Journal of Engineering Science \& Technology Review, 12(3), 164-171. https://doi.org/10.25103/jestr.123.22

Ke, X., Chen, H., \& Hong, Y. (2017). Do China's High-speed-rail projects promote local economy? Evidence from a panel data approach. China Economic Review, 44, 203-226. https://doi.org/10.1016/j.chieco.2017.02.008

Levinson, D. M. (2012). Accessibility impacts of high-speed rail. Journal of Transport Geography, 22, 288-291. https://doi. org/10.1016/j.jtrangeo.2012.01.029

Li, X.-J., Huang, B., Li, R.-R., \& Zhang, Y.-P. (2016). Exploring the impact of high speed railways on the spatial redistribution of economic activities - Yangtze river delta urban agglomeration as a case study. Journal of Transport Geography, 57, 194-206. https://doi. org/10.1016/j.jtrangeo.2016.10.011

Li, X. S., \& Su, B. (2017). Does opening high-speed rail facilitate agglomeration of manufacturing industry in regions? A quasi natural experimental study on BeijingGuangzhou high-speed rail. China Soft Science, 7, 81-90.

Liu, N. Q., \& Wu, Y. (2017). Does market expansion in Yangtze River delta can facilitate co-economic growth? Chinese Industrial Economics, 2017(6), 79-97. https://doi. org/10.19581/j.cnki.ciejournal.2017.06.019
Martínez Sánchez-Mateos, H. S., \& Givoni, M. (2012). The accessibility impact of a new high-speed rail line in the UK: A preliminary analysis of winners and losers. Journal of Transport Geography, 25, 105-114. https://doi. org/10.1016/j.jtrangeo.2011.09.004

Monzón, A., Ortega, E., \& López, E. (2013). Efficiency and spatial equity impacts of high-speed rail extensions in urban areas. Cities, 30, 18-30. https://doi.org/10.1016/j. cities.2011.11.002

Qin, Y. (2017). No county left behind? The distributional impact of high speed rail upgrades in China. Journal of Economic Geography, 17(3), 489-520. https://doi.org/10.1093/jeg/lbw013

Qin, C.-L., \& Chai, Q.-Y. (2018). Traffic network construction and integrated development in Guangdong - Hong Kong Macao Greater Bay Area. China Soft Science, 2017(7), 71-79.

Shao, S., Tian, Z., \& Yang, L. (2017). High speed rail and urban service industry agglomeration: evidence from China's Yangtze River delta region. Journal of Transport Geography, 64, 174-183. https://doi. org/10.1016/j.jtrangeo.2017.08.019

Shaw, S.-L., Fang, Z., Lu, S., \& Tao, R. (2014). Impacts of high speed rail on railroad network accessibility in China. Journal of Transport Geography, 40, 112-122. https://doi. org/10.1016/j.jtrangeo.2014.03.010

Tormo-Carbó, G., Oltra, V., Klimkiewicz, K., \& Seguí-Mas, E. (2019). "Don't try to teach me, I got nothing to learn": Management students' perceptions of business ethics teaching. Business Ethics: A European Review, 28(4), 506-528. https://doi.org/10.1111/beer.12236

Urrutia-Azcona, K., Fontan-Agorreta, L., Javier Diez-Trinidad, F., Rodriguez-PerezCuriel, F., \& Vicente Gomez, J. (2018). Smart zero carbon city readiness level: indicator system for city diagnosis in the Basque country moving towards decarbonization. DYNA, 93(3), 332-338. https://doi.org/10.6036/8476

Vaturi, A., Portnov, B. A., \& Gradus, Y. (2011). Train access and financial performance of local authorities: greater Tel Aviv as a case study. Journal of Transport Geography, 19(2), 224-234. https://doi.org/10.1016/j.jtrangeo.2010.02.008

Verma, A., Sudhira, H. S., Rathi, S., King, R., \& Dash, N. (2013). Sustainable urbanization using high speed rail (HSR) in Karnataka, India. Research in Transportation Economics, 38(1), 67-77. https://doi.org/10.1016/j.retrec.2012.05.013 


\section{Economics}

Vickerman, R. (2015). High-speed rail and regional development: the case of intermediate stations, Journal of Transport Geography, 42, 157-165. https://doi.org/10.1016/j. jtrangeo.2014.06.008

Wang, K., Xia, W., \& Zhang, A. (2017). Should China further expand its high-speed rail network? Consider the low-cost carrier factor. Transportation Research Part A: Policy and Practice, 100, 105-120. https://doi. org/10.1016/j.tra.2017.04.010

Xheneti, M., Smallbone, D., \& Welter, F. (2013). EU enlargement effects on cross-border informal entrepreneurial activities. European Urban and Regional Studies, 20(3), 314-328. https://doi.org/10.1177/0969776411434849

Xie, Z. (2018). Speed limit safety of expressway curves based on the critical state evaluation model of vehicle side rollover. Journal of Engineering Science \& Technology Review, 11(1), 109-116. https://doi.org/10.25103/ jestr.111.13
Yang, Y. R., Dobruszkes, F., Wang, J., Dijst, M., \& Witte, P. (2018). Comparing China's urban systems in high-speed railway and airline networks. Journal of Transport Geography, 68, 233-244. https://doi.org/10.1016/j. jtrangeo.2018.03.015

Yin, M., Bertoloni, L., \& Duan, J. (2015). The effects of the high-speed railway on urban development international experience and potential implications for China. Progress in Planning, 98, 1-52. https://doi.org/10.1016/j. progress.2013.11.001

Zhao, D. X., Han, Z. L., Wang, L., \& Zhao, B. (2015). Basic pattern of regional division of labor in Circum-Bohai Sea areas. Economic Geography, 35(6), 8-16. https://doi. org/10.15957/j.cnki.jjdl.2015.06.002

Zhao, W., \& Chen, Y. F. (2018). Location distribution effect of high-speed rail: Study based on theory and empirical evidences. Comparative Economic and Social Systems, 5(3), 44-52. 